\title{
Electric Energy Potential from Pineapples and Potatoes
}

\author{
Atikah Nur Syahirah $^{1^{*}}$, Riska Cahyati ${ }^{2}$ \\ Department of Chemistry, Faculty Of Mathematics annd Natural Sciences, State University of Medan, \\ Jl. Willem Iskandar Pasar V Medan Estate, Medan 20221 Indonesia \\ *Email : atikahnursyahirah22@gmail.com
}

\begin{abstract}
Basically, the voltage can be obtained from various sources, including fruit. Fruit is often used as food, drink and a source of vitamins for the body's defense system. It turns out that it has the ability to generate electricity, especially for fruit that has a high acidity level. The acidity in some types of fruit is able to generate electricity because it is electrolyte. Fruits which contain mineral acids in the form of hydrochloric acid and citric acid, are strong electrolytes that break down completely into ions in a water solution. Besides having acid, fruits also contain a lot of water, so that when two different metals are immersed, the fruit solution will create a potential difference between the metal and water so that there is an electrode potential that can generate electric current as well. The purpose of making a rough draft of this practicum is to prove the existence of electrical energy in pineapples and potatoes. In this experiment, it has been proven that pineapples and potatoes can produce an electric current, indicated by the presence of a voltage when measured by a voltmeter.
\end{abstract}

Keywords: energi potensial, voltmeter, listrik

\section{Pendahuluan}

Nanas adalah buah tropis dengan daging buah berwarna kuning memiliki kandungan air 90\% dan kaya akan Kalium, Kalsium, lodium, Sulfur, dan Khlor. Selain itu juga kaya Asam, Biotin, Vitamin B12, Vitamin E serta Enzim Bromelin.Nanas merupakan komoditas unggulan di Sumatera Selatan. Pada tahun 2006 produksi panen nanas di Sumatera Selatan mencapai 141.542 ton/tahun, peringkat ke tiga setelah Jawa Barat dan Lampung. Permintaan pasar dalam negeri terhadap buah nanas cenderung meningkat sejalan dengan pertumbuhan jumlah penduduk, semakin baik pendapatan masyarakat, dan semakin tinggi kesadaran penduduk tentang nilai gizi dari buahbuahan.Nanas termasuk komoditas buah yang mudah rusak, susut, dan cepat busuk.Oleh karena itu, seusai panen memerlukan penanganan pasca panen, salah satunya dengan pengolahan.

Nanas merupakan tanaman buah berupa semak yang memiliki nama ilmiah Ananas comosus. Memiliki nama daerah danas (Sunda) dan neneh (Sumatera). Dalam bahasa Inggris disebut pineapple dan orang-orang Spanyol menyebutnya pina.Nanas berasal dari Brasilia (Amerika Selatan) yang telah di domestikasi disana sebelum masa Colombus.Pada abad ke-16 orang Spanyol membawa nanas ini ke Filipina dan Semenanjung Malaysia, masuk ke Indonesia pada abad ke-15.Di Indonesia pada mulanya hanya sebagai tanaman pekarangan, dan meluas dikebunkan di lahan kering di seluruh wilayah nusantara. Nenas sejenis tumbuhan tropikal dan berada dalam kumpulan bromeliad (Famili Bromeliaceae), tumbuhan yang rendah seperti herba (herbaceous perennial) 
dengan 30 atau lebih daun yang panjang, tajam mengelilingi batang yang tebal. Nenas biasanya berwarna hijau sebelum masak dan berubah menjadi hijau kekuningan apabila masak.Kulit buahnya bersisik dan "bermata" banyak.Selain dikenal sebagai sumber vitamin $\mathrm{C}$, buah nenas mengandung protein, asam organik, dan dektrosa. Nanas digolongkan dalam dua jenis mutu, yaitu mutu I dan II. Beberapa penentu mutunya adalah Kerusakan (\%): mutu $\mathrm{I}=$ maksimum 5; mutu $\mathrm{II}=$ maksimum 10; Busuk (\%): mutu $\mathrm{I}=$ =maksimum 1; mutu II=maksimum 2; cara uji SP-SMP-3111981. Kadar total padatan terlarut (\%): minimum 12. Kotoran: bebas kotoran; cara uji organoleptik. Warna buah cepat sekali berubah oleh pengaruh fisika misalnya sinar matahari dan pemotongan, serta pengaruh biologis (jamur) sehingga mudah menjadi busuk.Oleh karena itu pengolahan buah untuk memperpanjang masa simpannya sangat penting. ${ }^{1}$

Kentang yang memiliki nama latin Solanum tuberosum L. merupakan salah satu jenis sayuran subtropis yang terkenal di Indonesia. Daya tarik sayuran ini terletak pada umbi kentang yang kaya karbohidrat dan bernilai gizi tinggi. Di Indonesia kentang sudah dijadikan bahan pangan alternatif atau bahan karbohidrat substitusi terutama dalam pemenuhan kebutuhan gizi dan pangan masyarakat Indonesia di samping beras. Umbi kentang saat ini sudah menjadi salah satu makanan pokok yang penting di Eropa meskipun pada mulanya didatangkan dari daerah Amerika Selatan. Tumbuhan kentang ini berasal dari Amerika Selatan dan sudah dibudidayakan oleh para penduduk di sana sejak ribuan tahun yang lalu. Kentang sangat cocok untuk ditanam di dataran tinggi serta di daerah yang beriklim tropis. Kentang merupakan tumbuhan dikotil batangnya yang ada di atas permukaan tanah memiliki warna hijau. Warna dari batang ini juga dapat dipengaruhi oleh usia dari tanaman itu sendiri dan juga keadaan dari lingkungannya. Pada tingkat kesuburan tanah yang lebih baik ataupun lebih kering, pada umumnya warna dari batang tumbuhan yang lebih tua akan jauh lebih mencolok warnanya. Kentang merupakan lima kelompok besar makanan pokok dunia selain gandum, jagung, beras, dan terigu. Bagian utama kentang yang menjadi bahan makanan adalah umbi, yang merupakan sumber karbohidrat, mengandung vitamin dan mineral cukup tinggi. Hanya denganmakan 200 gram kentang, kebutuhan vitamin $\mathrm{C}$ sehari terpenuhi. ${ }^{2}$

Buah-buahan dalam kehidupan sehari-hari merupakan salah satu asupan antioksidan bagi tubuh manusia. Buah sering dijadikan sebagai makanan, minuman dan sumber vitamin untuk sistem pertahanan tubuh. Banyak manfaat yang didapatkan manusia dengan mengkonsumsi buahbuahan. Ternyata buah bukan untuk makanan manusia saja, tetapi bisa dijadikan sumber listrik. Pada dasarnya, tegangan listrik dapat diperoleh dari berbagai sumber termasuk buah. Buah sering dijadikan sebagai makanan, minuman dan sumber vitamin untuk sistem pertahanan tubuh ternyata memiliki kemampuan untuk menghasilkan listrik khususnya untuk buah yang memiliki tingkat keasaman yang tinggi. Keasaman pada beberapa jenis buah mampu menghasilkan listrik karena bersifat elektrolit. ${ }^{3}$ Buah-buahan yang mengandung asam mineral berupa asam klorida dan asam sitrat, merupakan elektrolit kuat yang terurai sempurna menjadi ion dalam larutan air. Buah-buahan selain memiliki asam, juga banyak mengandung air, sehingga apabila ada dua logam yang berbeda dicelupkan, pada larutan buah-buahan tersebut akan timbul beda potensial antara logam dan air sehingga terjadilah potensial elektroda yang dapat menghasilkan arus listrik juga. ${ }^{4}$ Hal ini sejalan pula dengan prinsip sel volta. Jika dua buah logam dicelupkan dalam larutan elektrolit, maka akan terjadi reaksi spontan (reduksi-oksidasi) sehingga menimbulkan arus listrik. Dari konsep dasar ini, maka buah-buahan dapat digunakan sebagai sumber energi listrik alternatif. ${ }^{5}$

Di masyarakat kita, buah hanya dimanfaatkan sebagai sumber makanan, banyak dari kita yang tidak mengetahui bahwa ternyata buah (khususnya yang memiliki sifat asam) dapat pula dijadikan sebagai sumber energi listrik.Salah satu buah yang memiliki sifat asam dan mengandung air adalah buah nanas.

Adanya kandungan listrik pada kentang karena kentang mengandung garam dan air. Suatu garam apabila bereaksi dengan air akan menjadi larutan garam yang dapat menghasilkan listrik atau disebut dengan larutan elektrolit. ${ }^{6}$ Kentang juga mengandung zat pati, garam dapur $(\mathrm{NaCl})$ dan air (H2O). Yang dimana sebuah larutan elektrolit itu mempunyai tiga kmponen yaitu asam, basa, dan garam. 


\section{Metodologi Penelitian}

\subsection{Bahan kimia, peralatan dan instrumentasi}

Pada percobaan ini memakai beberapa alat dan bahan yaitu seperti buah nanas sebanyak 1 buah, kentang sebanyak 2 buah, uang logam yang kuning sebanyak 4 keping, paku sebanyak 4 buah ,penjepit buaya sebanyak 12 buah ,kabel sepanjang 2 meter dan dibagi menjadi 6 ,voltmeter sebanyak 1 buah dan pisau 1 buah.

\subsection{Prosedur penelitian}

Sediakan 1 buah nanas yang besar,kemudian dipotong menjadi 4 bagian sama besar. Gunakan pisau untuk membuat celah pada nanas untuk ditancapkan koin. Masukkan setengah dari koin ke dalam nanas. Tancapkan paku ke nanas,pastikan paku dan koin tidak bersentuhan . Setiap lempeng koin dan paku dijepit dengan penjepit buaya . Kedua ujung rangkaian dihubungkan dengan kabel dari voltmeter. Untuk lebih dari 1 nanas, hubungkan paku-uang koin dari nanas ke nanas yang berbeda.

Pada kentang,disediakan 2 buah kentang yang besar kemudian dipotong masing-masing menjadi 2 bagian,jadi jumlahnya menjadi 4 potong. Kemudian perlakukan hal yang sama dengan cara pengerjaan nanas.

\section{Hasil dan Diskusi}

Hasil yang didapatkan ketika diukur tegangan dengan voltmeter untuk buah nanas dan kentang ialah sebagai berikut:

Tabel 1. Tegangan buah nanas dan kentang

\begin{tabular}{|c|c|c|}
\hline No & $\begin{array}{c}\text { Buah Yang } \\
\text { Dipakai (Jumlah) }\end{array}$ & $\begin{array}{c}\text { Tegangan Yang } \\
\text { Dihasilkan }\end{array}$ \\
\hline 1 & Nanas (1 buah) & 1,1 Volt \\
\hline 2 & Nanas (2 buah) & 1,2 Volt \\
\hline 3 & Nanas (3 buah) & 1,3 Volt \\
\hline 4 & Nanas (4 buah) & 1,5 Volt \\
\hline 5 & Kentang (1 buah) & 0,8 Volt \\
\hline 6 & Kentang (2 buah) & 1,0 Volt \\
\hline 7 & Kentang (3 buah) & 1,1 Volt \\
\hline 8 & Kentang (4 buah) & 1,2 Volt \\
\hline
\end{tabular}

Pada buah nanas, dilakukan pada 4 potongan buah nanas sama besar dan masing masing ditancapkan koin dan paku dan dirangkai seperti pada gambar 1 . Hasil yang didapatkan ialah pada rangkaian di 1 potongan nanas,didapatkan tegangan sebesar 1,1 volt.

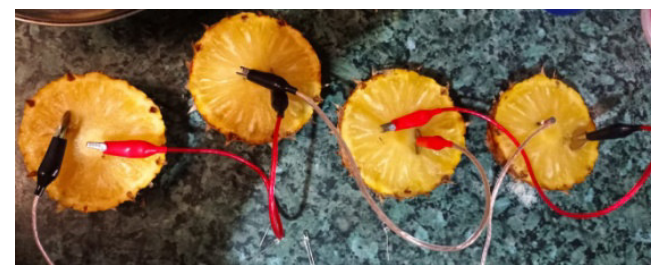

Gambar 1. 4 potongan buah nanas sama besar yang ditancapkan koin dan paku

Pada rangkaian di 2 potongan nanas,didapatkan hasil tegangan sebesar 1,2 Volt. Pada rangkaian di 3 potongan nanas,didapatkan hasil tegangan sebesar 1,3 Volt dan pada rangkaian di 4 potongan nanas didapatkan hasil tegangan sebesar 1,5 Volt.

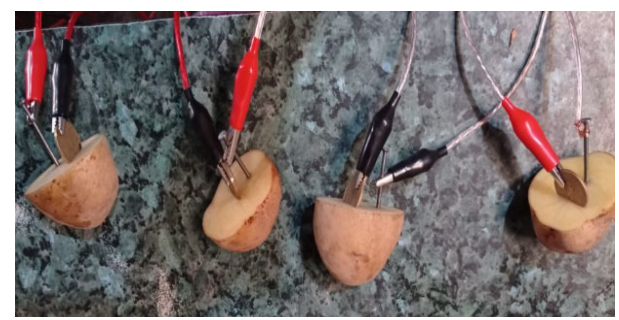

Gambar 2. 4 potongan kentang sama besar yang ditancapkan koin dan paku

Pada kentang, dilakukan oleh 4 potongan kentang juga sama seperti pada nanas yang sama besar dan masing-masing ditancapkan koin dan paku dan perlakuan yang sama pada nanas yang terlebih dahulu dilakukan. Rangkaian pada kentang dirangkai seperti pada gambar 2. Hasil yang didapatkan pada rangkaian di 1 kentang yaitu tegangan sebesar 0,8 Volt. Pada rangkaian di 2 kentang didapatkan tegangan sebesar 1,0 Volt. Pada rangkaian di 3 kentang didapatkan tegangan sebesar 1,1 Volt. Pada rangkaian di 4 kentang didapatkan tegangan sebesar 1,2 Volt. Semua tegangan diukur dengan Voltmeter.

Menurut percobaan yang telah dilakukan oleh buah nanas dan kentang, terbukti bahwa buah nanas dan kentang dapat menghasilkan arus listrik. Hal ini dibuktikan bahwa adanya arus tegangan pada buah nanas dan kentang yang telah diuji. Namun, buah nanas dan kentang dapat menghasilkan arus listrik bukan hanya karena buahnya, namun harus ada dan diingat ialah adanya Elektroda. Tanpa elektroda kentang dan nanas tidak dapat menghasilkan tegangan listrik, walaupun 
kentang dan nanas telah diketahui dapat menghasilkan arus listrik. Arus listrik dapat dihantarkan melalui katoda dan anoda.

Kandungan asam yang dimiliki oleh kentang dan nanas dapat digunakan sebagai larutan elektrolit. Suatu larutan dapat dikatakan sebagai larutan elektrolit jika zat tersebut mampu menghantarkan listrik. Zat elektrolit dapat menghantarkan listrik erat kaitannya dengan ionion yang dihasilkan oleh larutan elektrolit tersebut (baik positif maupun negatif). Suatu zat dapat menghantarkan listrik karena zat tersebut memiliki ion-ion yang bergerak bebas di dalam larutan tersebut. Ion-ion inilah yang nantinya akan menjadi penghantar. Semakin banyak ion yang dihasilkan semakin baik pula larutan tersebut menghantarkan listrik.

Dari hasil penelitian telah terbukti bahwa kentang dan nanas dapat menghasilkan listrik. Hal ini teramati dari bergeraknya jarum voltmeter ketika dihubungkan dengan ujung rangkaian yang disusun secara seri. Adanya listrik pada kentang dan nanas karena mengandung zat-zat yang merupakan komponen penghasil listrik. Dari uraian tersebut telah dijelaskan bahwa kentang dan nanas mengandung asam dan air. Asam merupakan suatu senyawa kimia sederhana yang terdiri dari dua atau lebih atom yang membawa ion positif (kation) dan ion negatif (anion). Adanya listrik dalam kentang dan nanas karena adanya reaksi asam dengan air yang menjadi sebuah larutan asam. Larutan asam merupakan suatu larutan elektrolit yaitu larutan yang dapat menghantarkan arus listrik. Oleh sebab itu, kentang dapat menghasilkan listrik.

Selain adanya asam dan air, faktor lain yang menyebabkan kentang dan nanas menghasilkan listrik ialah karena adanya reaksi ionisasi pada senyawa ion atau yang disebut dengan disosiasi. Senyawa ion tersusun atas ion positif (kation) dan ion negatif (anion). Senyawa ion akan terurai menjadi ion-ion (kation dan anion) ketika dilarutkan ke dalam air, sebab ion-ion di dalam air akan bergerak bebas. Ion-ion yang bergerak bebas ialah ion yang hanya terdapat dalam larutan dan lelehan. Kandungan asam pada kentang dan nanas merupakan suatu larutan, dimana asam merupakan zat terlarut dan air merupakan zat pelarut, sehingga ion-ionnya dapat bergerak dengan bebas. Gerakan ion-ion dalam kentang dan nanas tersebut yang dapat menghasilkan listrik.

Untuk mengetahui cara kentang dan nanas agar dapat menghasilkan listrik, yaitu dengan menggunakan teori sel Volta yang ditemukan oleh seorang ilmuwan bernama Alexander Volta dan Luigi Galfani, dimana kentang dan nanas merupakan elektrolit sedangkan paku besi dan logam merupakan sel elektrode. Paku besi dan logam merupakan Suatu elektrolit tidak dapat menghasilkan listrik jika tidak dihubungkan dengan suatu elektrode. Uang logam merupakan katode (kutub positif) sedangkan paku besi merupakan anode (kutub negatif). Reaksi antara elektrolit dan elektrode tersebut yang dapat mengahsilkan listrik. Kentang dan nanas merupakan suatu elektrolit. Untuk menghasilkan listrik, kentang dan nanas harus dihubungkan dengan elektrode berupa paku besi dan uang logam dan dirangkai secara seri.

\section{Kesimpulan}

Dari hasil penelitian telah terbukti bahwa kentang dan nanas dapat menghasilkan listrik. Hal ini teramati dari bergeraknya jarum voltmeter ketika dihubungkan dengan ujung rangkaian yang disusun secara seri. Adanya listrik pada kentang dan nanas karena mengandung zat-zat yang merupakan komponen penghasil listrik.

\section{Acknowledgement}

Terima kasih penulis kepada Tuhan Yang Maha Esa yang telah memberikan segala Berkat dan Rahmat-Nya sehingga penelitian ini dapat terlaksanakan dengan baik.

\section{Referensi}

1. U.M. Fadli., B. Legowo., \& B. Purnama. (2012). "Demonstrasi sel Volta buah nanas (Ananas comosus L. Merr)". Indonesian Journal of Applied Physics. 2(2), pp. 1-8.

2. S. Pamungkas. (2017, Apr). "Kentang sebagai bio listrik dengan penambahan enzim ptialin sebagai pengoptimal arus". PSEJ (Pancasakti Science Education Journal). 2(1), pp.48-55.

3. R.A. Syahputra., S. Rahmah., M.S. Syafei., F.N. Hidayah., M.E. Simanjuntak., R. Hutasoit., Y.A. Sitorus, \& Z.A. Barutu. (2020, Feb). "Battery construction from lime orange". Indonesian Journal of Chemical Science and Technology. 03(1), pp. 28-30 
4. A. Atina. (2015, Desember). "Tegangan dan Kuat Arus listrik dari Sifat Asam Buah". Sainmatika: Jurnal Ilmiah Matematika dan Ilmu Pengetahuan Alam. 12(2), pp. 28-42.

5. A.M. Setiawan., D. Nugraheni., M. Munzil., M.F. Marsuki., N. Husnayaini., \& Hanifiyah. (2020). "Pembuatan sel baterai berbasis bahan alam melalui pembelajaran stem". INKUIRI: Jurnal Pendidikan IPA. 9(1), pp. 1-5.

6. L. Utami \& Y. Fatisa. (2019, Jan). "Electricity production from peat water uses microbial fuel cells technology". Indonesian Journal of Chemical Science and Technology. 02(1), pp. 55-60 